\title{
Marine Practice Teaching based on School- Enterprise Cooperative Education Model
}

\author{
Lijun Wang, Sisi Wang*, Yongqiang Zhuo \\ Navigation College \\ Guangdong Ocean Universty \\ Zhanjiang, China \\ Corresponding Author: mars32lin@sina.com
}

\begin{abstract}
To solve the low quality of marine practice teaching, caused by limited training ship number and type, few practice route and high practice expense, the necessity and feasibility of school-enterprise cooperation in maritime education are discussed in accordance with the maritime education in China. By analyzing the existing domestic and international cooperation models together with their problems, more reasonable cooperation models of marine practice teaching are brought up under school-enterprise cooperative education model, which has important significance for application oriented shipping personnel training. Further more, the conflict between school and enterprise is discussed, and the cooperative education model is only effective in condition of win-win situation. It is necessary to establish state-run training fleets for the marine students and the instructor team too. At last, the cooperation education model based on school-enterprise-industrygovernment is brought up for further reforming of maritime education to adapt to the needs of the modern shipping industry.
\end{abstract}

Keywords- Marine Practice Teaching; School-Enterprise Cooperation; Maritime Education; Practice Fleet; China

\section{INTRODUCTION}

Over the past 10 years, the shipping industry has experienced a great fluctuation, and the maritime education in this background has made a rapid development, but there are some problems that need to be solved, such as the imbalance of the crew number, the will of the graduates working on the board, the uneven quality of the maritime education, and so on. The above problem in comprehensive universities is more prominent, on the one hand, the graduates employment rate decreased year by year, as the shipping industry in recession, the rate has from $100 \%$ before 2010 decreased year by year to about $50 \%$, and in recent years the adjustment of the salary of senior officers, making students' working on board will also decline, which is negative for improving the quality of maritime education. That is to say that the maritime education and the needs of the enterprise are not harmonious; on the other hand, the practice teaching of current maritime education is not appropriately arranged and lack of teaching funds. Especially for comprehensive Universities, the practice hours and double qualified teachers are not up to standard, as shown in Tab.1. Theoretical teaching is not harmonious with practical teaching and the operation ability and situational adaptability obviously can not meet the requirements of maritime work.

Especially in the transition period of China's economic development, the State Council has issued the decision on accelerating the development of modern vocational education, and Ministry of education 2014 annual work points clear that a number of undergraduate colleges and universities will be transited to the application of technical colleges and universities. It is obvious that maritime education is highly integrated with diploma education and vocational education. Consequently, it should speed up the pace of reform to adapt to the needs of the modern shipping industry.

In the future, the maritime education should strengthen the training of the crew members, and pay attention to the training of the management personnel of the shipping industry. School-Enterprise cooperative education (SECE) model can meet both requirements. If the enterprise becomes a part of the classroom, the students can learn skills of navigation on board, at the same time, experience the enterprise management, which is important for training seaman with management potential.

\begin{tabular}{|} 
Table. 1 Comparison of Marine Practice among Countries \\
\begin{tabular}{|c|c|c|c|}
\hline Country & Practice Time & Cost Source & Ship ownership \\
\hline China & 3 months & uncertain & uncertain \\
\hline Japan & 3 months & government & $\begin{array}{c}\text { Maritime Training } \\
\text { Institute }\end{array}$ \\
\hline Denmark & 3 terms & government & $\begin{array}{c}\text { Maritime Safety } \\
\text { Administration }\end{array}$ \\
\hline Norway & 4 terms & $\begin{array}{c}\text { shipowners' } \\
\text { association }\end{array}$ & $\begin{array}{c}\text { shipowners' } \\
\text { association }\end{array}$ \\
\hline German & 2 terms & government & College or Company \\
\hline Sweden & 2 terms & government & College or Company \\
\hline
\end{tabular}
\end{tabular}

Propositions on establishing state-run fieldwork fleets for the marine students are brought up in [1], which is possible in Europe [2]. Exploration on the training mode of school enterprise cooperation in the development of the adult Maritime Education is discussed in [3], and it has a international mode [4]. An effective way to deepen the cooperation between higher vocational education and the school enterprise under the new situation is described in [5], which will promote the development of China's maritime education [6]. The construction of school 
enterprise cooperation mechanism in maritime education is necessary [7], and it is effective in marine practice [8-11], which is to accelerate the reform of maritime education with scientific research as the bridge between university and enterprise cooperation [12].

The layout of the paper is as follows. In Section 2, the necessity and feasibility of school-enterprise cooperation in maritime education are discussed. In Section 3, the existing cooperation models and their problems are listed. In Section 4, more reasonable cooperation modes of marine practice teaching are brought up. Finally, Section 5 concludes the paper.

\section{NECESSITY AND FEASIBILITY OF SCHOOL- ENTERPRISE COOPERATION IN MARITIME EDUCATION}

In order to solve the problems of maritime education, the domestic and international experience shows that the enterprise should been integrated into the education. If the employer and the students can communicate with each other in advance, it is conducive to meet the requirements of training complex maritime personnel, but also to promote the development of the entire maritime industry. Cooperative education between schools and enterprises is the inevitable trend of marine education, especially in the marine practice teaching has obvious advantages, as shown in Fig. 1. At the same time, the communication is very important, and only a win-win solution is valuable in the capital society. At the present, different maritime universities belong to different level and state institutions, so the marine practice under SECE will meet different questions. For universities like Dalian Maritime University (DLMU), the shipping companies are willing to cooperate with them, because DLMU is the symbol of power in China. However, for local universities, the situation may not be optimistic. This is a realistic problem that can not be avoided. If both sides confirm to principle of mutual benefit and reciprocity, the cooperation will promote the marine practice greatly.

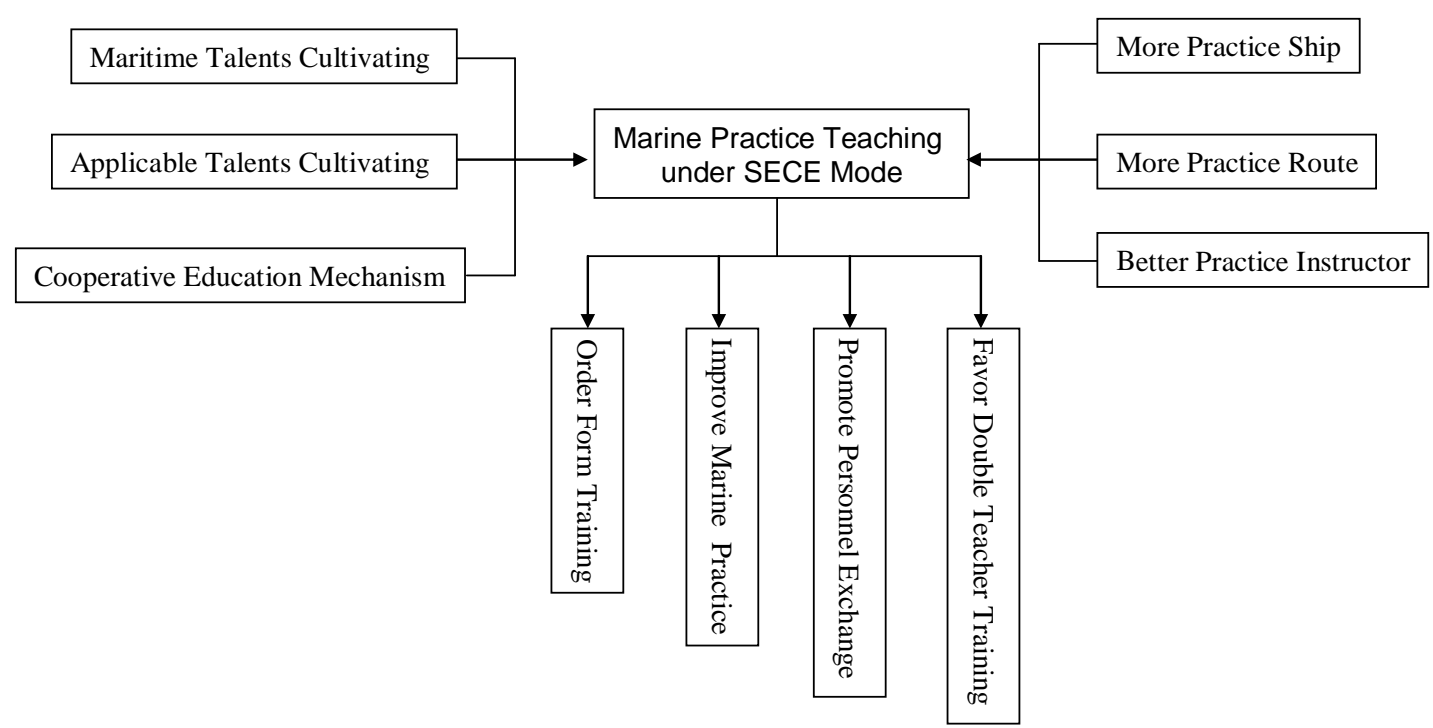

Figure 1. Advantages in Marine Practice of School-Enterprise Cooperative Education

\section{EXISTING SECE MODELS AND THEIR PROBLEMS}

Up to now, there are more than 80 maritime institutions of different kinds, and annual training of marine graduates have been more than 20000, but the number of special training ship and the students in the school are not matched. So it gave birth to the rich and colorful sea practice teaching mode, which mainly has the following models:

- University independently owns training ship, such DLMU and Shanghai Maritime University (SMU), which have very advanced specialized training ships. The advantage is that it can meet the requirements of the marine practice. But construction and the operating costs are high, so it is impossible for ordinary universities without special grants from the government. Beside that the ship type is fixed and relatively simple.

- Universities and shipping companies establish internship bases, which is a common form to solve the maritime practice for general colleges and universities, such as the ro-ro ships in the Qiongzhou Straits and Bohai Gulf. However, the bases in big shipping companies with ocean or coastal routes is too less. The effects of marine practice decline greatly because of short routes, short voyage schedules, fixed ship type and so on, especially for the training effect of the students in the navigation of unlimited navigation area.

- Universities sign agreements with the shipping company with the teaching training ship, and the universities are responsible for all costs. For example, Jiangsu Maritime Institute (JMI) signs agreements with Shanghai Yuhai shipping company (SYSC). SYSC is responsible to provide ocean teaching training ship 'YUFENG', high quality crew, appropriate teaching plan and strict management system. JMI is in charge of full costs for a period of 7 days of ocean voyage practice, arrange professional teachers to form a teaching team together with 'YUFENG' crew, and is responsible for the daily management practice training of students. This is a very meaningful attempt to carry out the marine practice teaching under SECE mode. The main difficulty is the practice fees, which is beyond the universities' 
capacity to pay and make the practice period too short.

- By building a training ship or transforming the existing ship into training ship, the universities and shipping companies have brought up an effective marine practice teaching under SECE mode. For instance, Wuhan University of Technology (WHUT) builds 2 ships together with China Changjiang National Shipping Cooperation (CSC), such as 45 000t bulk ships 'Changhang Xinghai' and 'Changhai Fuhai'. Each ship has been equipped with synchronous simulation training facility, along with student special multimedia classroom, dining room, accommodation for 36 people, instructors' cabins and other living facilities. This model has solved the problems such as the marine practice teaching, the training of the double-professional teachers and the platform of maritime scientific research. The model has developed rapidly in recent years, and there are already Jimei University, Guangzhou Maritime Institute, Qingdao Ocean Shipping Mariners College. The only problem is that the model cannot benefit all universities.

\section{Marine Practice Teaching Model under SECE}

At present, students of navigation technology major can have marine practice on board ships about 3 months, compared with the Western European countries, the marine practice time is short. The main difficulty is the lack of training ship, and the real problem is the funding. Although some universities can build their own training ships, such as DLMU, SMU, WHUT and JMU, the operating fees also trouble them, especially in the case of the shipping industry downturn. Until now, the main funding source is from government appropriation.

The two sides shared model has achieved good effect, but trouble is always there. Ownership belongs to both parties. However, the universities are biased towards practice rather than profits, and vice verse, as shown in Fig. 2. So contradictions between two parties are obvious and mutual sacrifices are needed, especially when shipping industry is on the peak or trough.

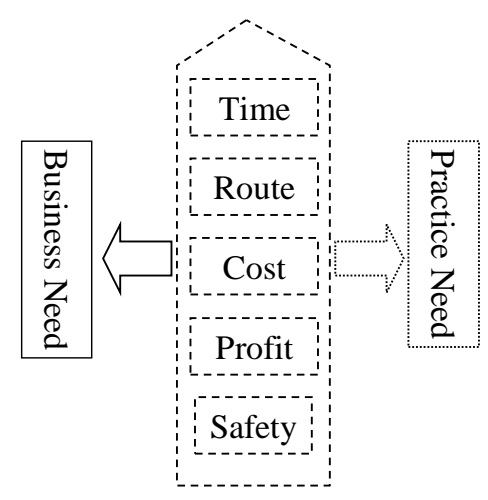

Figure 2. Conflict factor between university and company

Above indicates that the training ship is too less to improve the marine practice further. It is necessary to promote the SECE mode by increasing the training ship number. Specific practices of training fleet are as follows, firstly, the competent authority should cooperates with shipping companies and maritime universities under the premise of the coordination of the industry overall; secondly, the each shipping company should establish a certain number of training ship or reconstruct existing ships, forming training fleet; thirdly, a coordination center shall be established to distribute the training ship unified in accordance with different teaching plan. The cost should be overall planning by administration, universities and companies. However, the cost should be funded by the government due to international custom and public welfare of seafarers' cultivation. In a word, only if all parties in shipping industry reach a consensus, the marine practice under SECE will be implemented in practice. Furthermore, only if capacity of the training fleet matches the number of personnel training, the marine practice will be carried out in accordance with STCW requirements. Training fleet can be national or local, such as the training fleet of China or Guangdong Province.

Meanwhile, a practice instructing expert team shall be set to improving the practice on board the training fleet. At present, the teachers of universities are in charge of the practice instructing. However, the crew members on board the ship, especially the senior officers, have good seamanship, which is important for students' navigational skill training. Consequently, if the senior officers have the instructor qualification certificate (IQC), or the teacher has the certificate of competency (COC), they will be instructor team members, as shown in Fig. 3. Because of the double responsibilities on board the training ship, that is to ensure the safe production and to educate marine personnel, additional salary shall be paid to members of instructor team. Until now, the competency and qualification standard of marine practice instructor has not been made. However, the standard is necessary because of the importance of safe working and personnel cultivating.

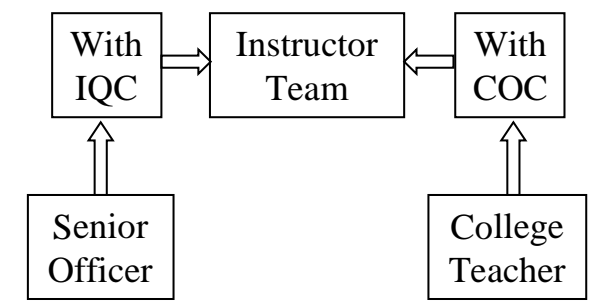

Figure 3. Members of Instructor Team

The advantages of marine practice under SECE do great good to students. For example, there are more training ship types and routes, so the students can know more about the working characteristics of different ships and routes in advance, which will make them make the best professional choice. If the practices make them fall in love with the selected ship, they will entry into professional role early; otherwise, they get a second chance. It is of important significance for the formation of dedication for maritime graduates. In addition, the size of training fleet is depending on the number of navigational personnel, the coordination among parties must be effective to make full use of the fleet.

To explore various kinds of marine practice, enterprises and colleges shall deepen the cooperation. It is advised to carry out ' $3+1$ ' and ' $1+x$ ' double mode. The students will carry on the theory and the general skill 
training in school for 3 years, which is to cultivate students' basic theory, safety awareness and practical ability. At the same time, the students will pass the competency assessment and examination of MSA, and then the students will get the chance to work on board ships. In the last year, they will practice in shipping companies to obtain navigational skills and necessary seamanship. At last, the students will get 1 diploma and several COCs and DOCs.

The multi-level maritime education system has been established in China, and the maritime education has the functions of diploma education and vocational education. Especially at present, working on board is not compulsory, that is to say, different treatment should be put on different students. If the students are willing to work on board, the fee should be paid by the government or the company. For the students not willing to work on board, the marine practice can be substituted with Subject paper or training by large ship handling simulators.

\section{OUTLOOKS AND CONCLUSIONS}

\section{A. Outlooks}

The cooperative education between universities and shipping companies is the form of marine practice. If there are no supports from the administration and far from the industry development, the marine practice will not be carried out smoothly and the benefit is too limited.

In the current industry background, the schools should change the passive role, to take the initiative to contact and coordinate with other parties to provide more training ships and route; on the other side, the colleges shall keep in mutual cooperation to realize the sharing of various kinds of practice resources for students and the industry in the future.

From the above, it is known that institutions are the main body of the training of maritime personnel, the needs of the enterprise and the development of the industry are the guidance, and the support of government administration is the guarantee. Consequently, the cooperative education of 'university, government, industry and enterprise' is the next step for marine practice of maritime education, as shown in Fig. 4.

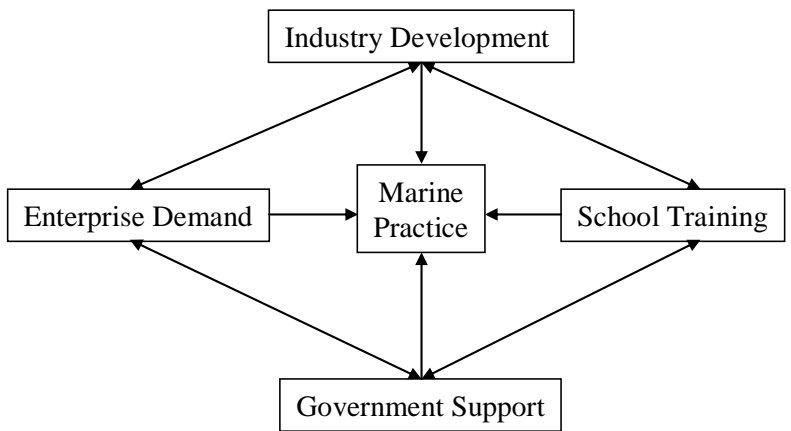

Figure 4. Marine practice under cooperative education of 'university, government, industry and enterprise'

\section{B. Conclusions}

To solve the low quality of marine practice teaching, caused by limited training ship number and type, few practice route and high practice expense, a more efficient method is brought up to carry out marine practice teaching, that is school-enterprise cooperative education model, which has important significance for application oriented shipping personnel training. The necessity and feasibility of school-enterprise cooperation in maritime education are discussed in accordance with the maritime education in China. By analyzing the existing cooperation models and their problems, more reasonable cooperation modes of marine practice teaching are brought up. Finally, the marine practice under cooperative education of 'university-government-industry-enterprise' is discussed and will be studied further more in the next step.

\section{ACKNOWLEDGMENT}

This work was supported by education reform projects of the education department of Guangdong Province (GDOU2013040612, GDOU2013040611) and education reform project of Guangdong Ocean University (XJG201516).

The authors also gratefully acknowledge the helpful comments and suggestions of the reviewers, which have improved the presentation

\section{REFERENCES}

[1] Xianqiang Li. Propositions on Establishing State-run Fieldwork Fleets for the Marine Students. Journal of Qingdao Ocean Shipping Mariners College, vol. 30, Mar. 2009, pp:19-22.

[2] China Transport Bureau. Maritime Education Report of Europe. Maritime Education Research, vol. 19, Dec. 2002, pp:27-33.

[3] Cheng Qian. Exploration on the training mode of school enterprise cooperation in the development of the adult Maritime Education. Science \& Technology Information, vol. 21, Jul. 2011, pp204-205.

[4] Shi Zhufeng, Qiao Feng. Research on Internationalization of Maritme Education based on School-Enterprise Cooperation Mode. Journal of Nantong Vocational College, vol. 27, Sep. 2013, pp3337.

[5] Wei Guirong, Jiang Fei. An effective way to deepen the cooperation between higher vocational education and the school enterprise under the new situation. Maritime Education Research, vol. 32, Mar. 2015, pp:5-7.

[6] Gao Yude. Carry out all aspects of school enterprise cooperation to promote the development of China's Maritime Education. Maritime Education Research, vol. 27, Mar. 2010, pp:1-3.

[7] Chen Gang. The construction of school enterprise cooperation mechanism in Maritime Education. Maritime Education Research, vol. 23, Jun. 2006, pp:1-4.

[8] Ye Mingjun. Research on the "navigation cognition practice" of Maritime Education Based on the cooperation between enterprises and enterprises. Education and Vocation, Feb. 2012, pp162-163.

[9] Ding Zhenguo. On the construction of the Higher Vocational Maritime enterprise cooperation system. Maritime Education Research, vol. 29, Jun. 2012, pp:42-44.

[10] Lv Qing. A study on the training center of the maritime skills of the four sides of the government and the school enterprise. Zhong Guo Shuiyun. Nov. 2011, pp28-30.

[11] Wang Jianping, Wang Bo. An exploration of the mode of enterprise cooperation in the cultivation of marine talents. Maritime Education Research, vol. 28, Dec. 2011, pp:26-28.

[12] Zhan Yulong, Chen Baozhong, Zeng Xiangming. To accelerate the reform of maritime education with scientific research as the bridge between University and enterprise cooperation. Maritime Education Research, vol. 20, Mar. 2003, pp:18-20. 